\title{
Practices of Politicizing Listening (to Migration)
}

\author{
Nanna Heidenreich
}

Already, before the 'summer of migration' in 2015-the supposed 'refugee crisis' - strategies such as 'giving a face' and 'lending a voice' have become catch phrases in addressing migration and flight. However, no voice is just nature, reality, truth, or simply 'there'. In particular, what a voice is, can do, is also a question of listening. The famous question posed by Gayatri Chakravorty Spivak is pertinent here: 'Can the subaltern speak?' Pointedly, her response reveals that the answer to this question is based on the subaltern voice getting heard. In this way, listening plays a crucial role: it critically allows a voice to be heard. Such active listening is an act of response rather than a simple act of recording; it does not defer responsibility by placing it on 'the Other's' ability to speak, to find their voice within the frame given to them in the act of 'giving' or 'lending'.

The German term Aufnabme speaks volumes here with its threefold translations as recording, admission and inclusion. ${ }^{1}$ Replacing the long established German neologism of Nichteinwanderungsland (a country of

\footnotetext{
'The point of language will no longer only be about communication, but also about pleasure and politics'
}

\author{
N. Heidenreich $(\bowtie)$ \\ ifs internationale filmschule köln, Berlin, Germany
}

(C) The Author(s) 2019

P. Hildebrandt et al. (eds.), Performing Citizenship, Performance

Philosophy, https://doi.org/10.1007/978-3-319-97502-3_18 
non-immigration), the term Aufnabmegesellschaft became a keyword in 2015. It means host society, referring to the moment of arrival as well as to civil society's active engagement in providing support and many of the services German bureaucracy actually fails to provide for migrants and refugees. ${ }^{2}$ What the term misses is the incorporation of duration-it inherits, after all, the well-established frame of non-immigration. The question therefore continues to be: how to think arrival-The Enigma of Arrival, as V. S. Naipaul titled his 1987 novel—or, how to think Aufnabme. One way to do so might lie in the semantic layers of the word: let's turn to the sound of Aufnabme, let's listen to arrival, let's think migration through the ear.

Philip Scheffner's films testify to the art of listening as a form of (political) activation. In 2012, he and his co-author Merle Kröger ${ }^{3}$ made a film about the death of Grigore Velcu and Eudache Calderar, two Romanian Roma who were shot at the German-Polish border in 1992, supposedly a hunting accident. The German hunters responsible for their deaths claimed they thought the men they spotted in the wee hours of the morning in a corn field were wild boar; they were put on trial and acquitted. The families of the men who were killed were never informed about the trial. Not one single representative of the law nor any other involved party considered contacting them, thus depriving them of a chance to participate in negotiating justice and having the possibility to make civil claims. Instead of reading this violent inactivity as individual or group negligence or failure, rather, this configuration needs to be understood as an expression of structural violence (which does not dilute individual responsibility). Through their film, titled Revision, Scheffner and Kröger set out to open a space for negotiation withheld by police investigations and court proceedings. The very space which the systematic violence of racism, bureaucracy and diffused responsibility foreclosed. In reopening a legally terminated case for a different agenda, a new 'hearing room', ein newer Verhandlungsraum could emerge. A space was created in which the families of the victims could participate, as well as all the other parties involved; a cinematic revision in which reflection on the very form of the witness testimony gives shape to a listening/recording practice allowing for voices to be heard which were silenced before. The film did not aim to produce a different judgment, but created instead the possibility for different versions of contemporary European history to have meaning and resonance. The violence of the deaths and ensuing silence cannot be undone; thus, Revision does not resort to the narrative and institutional form of either 
the verdict or of revenge, two familiar sites of 'justice'. Instead, it opens up a space for speaking and, more so, for listening. The film documents their 'revision', their reviewing, rather than first encounters-the 'original' interviews. Each protagonist is shown listening to their prior statements. Everybody gets the chance to speak, to listen, and to comment. ${ }^{4}$

One of the participants in this process of revision was Colorado Velcu, the oldest son of Grigore Velcu. His presence in Revision is striking. He has a clear command of the position of the camera and of relational configurations in operation in the space that lies between who is behind the camera and who or what is in front of it, and what actually speaking within the camera's frame entails. He clearly has no interest in just 'giving' his face or his voice to the piece. He questioned the filmmakers and actively configured the meeting grounds, as Philip Scheffner and Merle Kröger have described in their encounter. ${ }^{5}$ It is their shared love for Bollywood that lays the foundation for mutual openings: cinema as a space of negotiation, also in its colorful grand version of song, dance, and endless passion.

A few years after the completion of Revision, Colorado Velcu, (temporarily) single father of seven, ${ }^{6}$ moved to Germany with parts of his extended family-first to Essen, then to Berlin. The relationship between Philip Scheffner and Colorado Velcu has always been via the camera. They set out to film their arrival; it is a form of communication (also in the absence of a shared language 'proper'). This begins to shift very quickly: the camera becomes several cameras, and Colorado Velcu - with the support of his family-begins to collaborate on what will become the film And-Ek Ghes... (2016). Fittingly, the film begins in a recording booth. We see Colorado Velcu wearing headphones, listening to a recording of his voice. He hears, we hear

I started a few times to write a personal diary. But that was all. I never managed to keep at it, even for a few weeks. Today, I've decided to write. As one sees, I've picked up my pen here in my apartment in Berlin. I begin with my arrival in Germany, in Essen. As I have to begin there.

He pauses and then begins to speak on camera, addressing Philip Scheffner, whose reflection we see in the soundproof glass of the recording booth: 
I think it wasn't so good. We should do it again. We can do it still better. Let's do it again.

And from the off, Philip Scheffner:

Ok.

And-Ek Ghes... means: 'One fine day...' A song, a promise to the beloved, to the children, to oneself. Members of the Velcu family-from Faţa Luncii, Romania-move to Berlin and perform themselves into a possible future. It is the refrain of the title song that was written by Colorado Velcu. It is this song that adds yet another layer to the many cinematic formats and languages deployed and worked through by Velcu and Scheffner in their film; they transform the piece into a Bollywood style music video that lays claim to a city and its venues: this is our story, our scenery, our stage.

Feminist theorist and musician Christina Thürmer-Rohr published an article in 1994 called 'Achtlose Obren. Zur Politisieren des Zubörens', translated as: 'Careless Ears. On the Politicization of Listening', 7 in which she establishes a connection between Aufnahme and Aufnabme: inclusion and recording, starting and absorbing, receiving and accommodating, taping and adopting. Aufnahme is the verb used to describe the current arrival of refugees and migrants. Aufnabme outlines the bureaucratic processes migrants have to pass through as imposed by the supposed 'host' society, that is Germany. As Aufnabme, the sites of their registration are called Aufnabmezentren, or 'reception centers'. These euphemisms should indeed be held by their word. Thürmer-Rohr writes:

Listening shows that the Other concerns me. It signals interest in the world, interest in the Other(s). Listening to is a metaphor for openness, a person's being open, hospitality on the inside. S/he who listens makes herself accessible and vulnerable, wants to know about the Other, is concerned by the Other, wants to answer to the Other. Listening to contradicts the monological consciousness, is not only reception but attention and irritation. ${ }^{8}$

Listening to is not about recognizing what one already knows,... it leads to something missing and not to something already known. ${ }^{9}$ 
It doesn't confirm or indeed reaffirm; it means slackening the realm of certainty and stepping into an arena of uncertainty.

Thinking about listening is not so much about advocating sound instead of images, as if the recording of sound would be less imbued with 'perspective' than recording with a camera. Listening as a political act is more about a shift in focus, a shift in the attunement of one sense by using another. Listening might actually teach us to see (otherwise).

Philologist and communication scholar Lisbeth Lipari, in a short article called 'Listening Others', ${ }^{10}$ addresses the practice of listening to the others as 'Other'. If we fail to do so, she argues, we 'deny their alterity and limit our own horizons of meaning. But when we listen to the other as other, we pave the way for an ethic that can listen others to speech, and in doing so, put our self-conceptions and dearly held certainties at risk. ${ }^{11}$ Lipari continues by looking at the transitive and intransitive uses of speaking, listening and hearing. She wants to convey a sense of listening as constitutive of, and prior to, speaking: 'listening is an invocation, a calling forth of speech'. ${ }^{12}$

In this sense, Judith Butler and Gayatri Chakravorty Spivak were listening together to the 2006 protests of illegalized immigrants in the US, who were collectively singing the US national anthem in Spanish. In their dialogue, 'Who sings the Nation-State. Language, Politics, Belonging', ${ }^{13}$ they hear it not simply as an expression of a new-a pluralist, more inclusive-nationalism, but rather, they hear it as the longing for enfranchisement. ${ }^{14}$ In German, this is translated as 'Verlangen nach Stimmrecht ${ }^{15}$ that is, the desire to enter the law, the desire for having the right to vote, and the longing for the right to have a voice: Stimme-voice, and Stimme-vote.

The doubling of the meaning of voice as Stimme und Stimmrecht, between voice and vote, gains another angle in the context of the films I chose as examples-it needs to be revisioned. If we discuss arrival under the premise of citizenship, that is, as a question of arrival in the sense of becoming part of the political community (which always also pertains to the question of rights, even if one considers citizenship as constituted from below), we need to ask again what this entails, as it is obviously not simply a question of legal status or passport. In the case of the Romanian Roma people, they-like all other EU citizens - have the right to establishment (in other words, residence). Yet Romanian Roma are clearly not treated as equal citizens, and even have been deported from countries such as France and Germany in blatant violation of the law-acts of unlawful 
violence enacted by the state. So, what if the entitlement to participate is not defined by one's passport (as in the case of Romanian Roma who are citizens with EU membership, but are still not counted in)?

One of the expressions of everyday racism in Germany has become the demand to speak German ('Here we speak German (only)!'). Monolingualism (as attitude) feeds into the use of the German language as a tool of exclusion and discipline. And yet, the critique of this form of violent refusal to speak, and thus to listen otherwise, does not mean that being able to relate to Otherness is based solely on knowledge. Understanding - or actually, the willingness to understand and to relatedoes not reside in subtitles, and most certainly not in the dubbing, to use another cinematic term. Eva-Ruth Wemme worked as one of the translators on the making of And-Ek Ghes.... Wemme is the author of the book

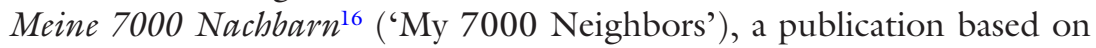
the blog under the same name, in which she chronicles her work as translator-and facilitator-with Romanians and, in particular, Romanian Roma in Berlin. When she was asked to work as a translator for the film, she expected a familiar situation:

When I interpret between Roma and Gajikané [non-Roma people, ed.], fear usually rises up against me - in the worst case, from both sides - and I need good standing. Two meet who can't understand one another, not just linguistically, and who also don't even believe understanding is fundamentally possible.

But:

Working with Philip and Colorado, nothing rose up against me. Unaccustomed to that, I started to totter. I almost felt superfluous; nothing hurt when we spoke. There were no cultural presuppositions or dreams that also needed to be interpreted. Philip and Colorado encountered one another in a world whose points of reference they had created themselves. They understood each other; it was only one another's words that were unfamiliar. A matter of the tools of my trade. And when, beyond the question of language, they didn't understand each other, they considered it as something to be expected. People can't see through one another like shards of glass. ${ }^{17}$

The ability to understand might thus be found elsewhere, in a different form of relation (to language, to speaking, and of course to listening). As 
Daniel Hendrickson-musician, author, translator and member of the artist collective CHEAP—writes in his 'The Rhizome of Babel', ${ }^{18}$

Each of us will speak whichever language he or she chooses, as the situation arises. The choice of language will be left to the speakers, to be negotiated according to ability, context, or simply personal whim. We will be free to switch from one to the other as we see fit. We will not be required to speak only one, and we will not even be required to announce which one it is that we are speaking. I will not require you to understand me, nor will I blame myself if I don't understand you. The point of language will no longer only be about communication, but also about pleasure and politics. After all, what is the point of 'nations and tribes' if it's not that we should get 'to know one another'? I may very well try to learn your language(s), but if I do, it probably means that I'm flirting with you. ${ }^{19}$

The film And-Ek Ghes... ends as it begins, with Colorado Velcu in the recording booth, a trace of Philip Scheffner visible in the reflection of the glass. Velcu reads from his diary. Then he looks up and addresses Philip, the camera, and us: 'Let's listen to it again. Let's see how it turned out.'

\section{Notes}

1. See Julia Tieke's working through the meanings of Aufnabme in her audio play 'Achtung, Aufnahme!', Recording in Progress! which she wrote and realized for the series Tonspuren/Soundtracks-I curated this work for the Haus der Kulturen der Welt in Berlin in 2015. http://hkw.de/en/programm/projekte/veranstaltung/p_128515.php, date accessed 31 January 2017.

2. See the two 'EFA' studies 'Strukturen und Motive der ehrenamtlichen Flüchtlingsarbeit (EFA) in Deutschland' conducted by BIM-Berliner Institut für empirische Integrations- und Migrationsforschung. https:// www.bim.hu-berlin.de/en/about/, date accessed 31 January 2017.

3. Together they formed the production platform 'pong' in 2001, http:// pong-berlin.de/, date accessed 31 January 2017.

4. See also the director's statement on the film's website: http://revisionfilm.eu/en/2/film-texts-revision/directors-statement, date accessed 31 January 2017.

5. For example, at the conference Wessen Wissen? in July 2016 at the University of the Arts in Berlin, https://www.udk-berlin.de/forschung/dfg-gradui- 
ertenkolleg-das-wissen-der-kuenste/veranstaltungsarchiv-des-dfg-graduiertenkollegs/wessen-wissen-kuenste-situiertheit-materialitaet/, date accessed 31 January 2017.

6. At the time of the making of the film, his wife-the mother of his children-was in prison in Romania.

7. Published first in Christina Thürmer-Rohr (1994) Verlorene Narrenfreiheit. Essays (Berlin: Orlanda), pp. 111-29.

8. Christina Thürmer-Rohr (1994) Verlorene Narrenfreiheit. Essays, (Berlin: Orlanda), p. 111 [author's translation].

9. Christina Thürmer-Rohr (1994) Verlorene Narrenfreiheit. Essays (Berlin: Orlanda), p. 115 [author's translation].

10. Published in Angus Carlyle \& Cathy Lane (2013) (eds) On Listening (Axminster/Devon: Uniformbooks), pp. 156-9.

11. Angus Carlyle \& Cathy Lane (2013) (eds) On Listening (Axminster/ Devon: Uniformbooks), p. 156.

12. Angus Carlyle \& Cathy Lane (2013) (eds) On Listening (Axminster/ Devon: Uniform books), p. 157.

13. Judith Butler \& Gayatri Chakravorty Spivak (2011) Who sings the NationState. Language, Politics, Belonging (London/New York/Calcutta: Seagull).

14. Judith Butler \& Gayatri Chakravorty Spivak (2011) Who sings the NationState. Language, Politics, Belonging (London/New York/Calcutta: Seagull), p. 63.

15. Judith Butler \& Gayatri Chakravorty Spivak (2007) Sprache, Politik, Zugehörigkeit, translated by Michael Heitz \& Sabine Schulz (Berlin: diaphanes), p. 44.

16. Eva-Ruth Wemme (2015) Meine 7000 Nachbarn (Berlin:Verbrecherverlag).

17. Eva-Ruth Wemme (2016) Everything Merely Language (Berlin), http:// andekghes.pong-berlin.de/en/10/eva-ruth-wemme, date accessed 26 March 2017. The text was written in German and, in that language, has a particular beauty, as has all of Wemme's writings.

18. Daniel Hendrickson (2011) 'The Rhizome of Babel' in Sebastian Cichoki \& Galit Eilat (eds) A Cookbook for Political Imagination (Berlin: Sternberg Press), pp. 232-5.

A Cookbook for Political Imagination was a publication for Yael Bartana's art/political enterprise 'The Jewish Renaissance Movement in Poland', a critical investigation of Zionism and of notions of origins and dreams of return, together with its mix into historical and present anti-semitism, as well as Schengen/Dublin Europe's anti-immigration politics.

19. Daniel Hendrickson (2011) 'The Rhizome of Babel' in Sebastian Cichoki \& Galit Eilat (eds) A Cookbook for Political Imagination (Berlin: Sternberg Press), p. 235. 
Open Access This chapter is licensed under the terms of the Creative Commons Attribution 4.0 International License (http://creativecommons.org/licenses/ by $/ 4.0 /)$, which permits use, sharing, adaptation, distribution and reproduction in any medium or format, as long as you give appropriate credit to the original author(s) and the source, provide a link to the Creative Commons licence and indicate if changes were made.

The images or other third party material in this chapter are included in the chapter's Creative Commons licence, unless indicated otherwise in a credit line to the material. If material is not included in the chapter's Creative Commons licence and your intended use is not permitted by statutory regulation or exceeds the permitted use, you will need to obtain permission directly from the copyright holder.

(c) $\underset{\mathrm{gr}}{\mathrm{g}}$ 